\title{
MENGUKUR RISIKO SISTEMIK DAN KETERKAITAN FINANSIAL PERBANKAN DI INDONESIA
}

\author{
Sri Ayomi \\ Bambang Hermanto ${ }^{1}$
}

\begin{abstract}
This paper measures the insolvency risk of bank in Indonesia. We apply Merton model to identify the probability of defaul tover 30 banks during the period of 2002-2013. This paper also identify role of financial linkage a cross banks on transmitting from one bank to another; which enable us to assess if the risk is systemic or not. The results showed the larger total asset of the bank, the larger they contribute to systemic risk.
\end{abstract}

Keywords : Conditional Value at Risk; Probability of Default; systemic risk and financial linkages; Value at Risk.

JEL Classification: D81, G21, G33

1 Sri Ayomi is bank supervisor on Financial Services Authority (OJK); (corresponding author: sriayomi@yahoo.com); Bambang Hermanto (may he rest in peace) is lecturer on Economic Department, University of Indonesia, (bhermanto78@gmail.com). 


\section{PENDAHULUAN}

Perbankan memiliki posisi strategis sebagai lembaga intermediasi dan penunjang sistem pembayaran (UU No. 10/1998). Sebagai lembaga intermediasi, perbankan dapat memberikan kemudahan untuk mengalirkan dana dari pihak yang memiliki kelebihan dana (savers) dengan kedudukan sebagai penabung ke pihak yang memerlukan dana (borrowers) untuk berbagai kepentingan. Selain itu, bank juga sebagai agent of development, yang dapat mendorong kemajuan pembangunan melalui fasilitas kredit dan kemudahan-kemudahan pembayaran dan penarikan dalam proses transaksi yang dilakukan para pelaku ekonomi.

Dalam melakukan fungsinya tersebut, sektor perbankan memiliki eksposur terhadap berbagai macam risiko. Untuk dapat menjalankan fungsinya dengan baik, sektor perbankan dituntut untuk mampu secara efektif mengelola risiko-risiko yang dihadapinya agar dapat memelihara kesinambungan proses bisnisnya sehingga proses intermediasi keuangan dalam perekonomian dapat berkelanjutan dan berjalan dengan efisien. Apabila bank telah mampu meraih tingkat efisiensi yang optimal maka akan mendukung roda perekonomian agar berjalan dengan baik.

Risiko sistemik merupakan faktor yang sangat menentukan dalam membangun stabilitas sistem keuangan di suatu negara karena financial imperfections antara lain asymetric information, agency problem, moral hazard menyebabkan excessive risk taking behavior, contagion risk (efek domino) dan prosiklisitas intermediasi keuangan.

Risiko sistemik dapat pula dinyatakan sebagai suatu risiko yang menyebabkan kegagalan dari satu ataupun beberapa institusi keuangan sebagai hasil dari kejadian sistemik (systemic events). Hal ini dapat berupa guncangan (shock) yang mempengaruhi salah satu institusi ataupun shock yang mempengaruhi institusi yang kemudian menyebar ataupun suatu shock yang secara simultan mengenai sejumlah besar institusi lain (De Bandt dan Hartmann, 2000 dan Zebua, 2010). Berbagai penelitian mengenai potensi risiko sistemik di industri perbankan menurut Saheruddin (2009) telah dilakukan di negara-negara Eropa (Nagy dan Fox, 2005); Amerika Serikat (Buehler dan Gupta, 1987); Brazil (Barnhill dan Souto, 2007) dan di beberapa negara di Asia seperti Jepang (Uchida dan Nakagawa, 2004) dan Sri Langka (Tennekoon, 2002).

Sedangkan Adrian dan Brunnermeier (2009) mengungkapkan bahwa untuk melakukan suatu pengukuran yang mengandung risiko sistemik sebaiknya dengan mengidentifikasi risiko yang terdapat pada suatu sistem dengan mengukur sistemik individu suatu institusi, dimana institusi ini saling terkoneksi dan berukuran besar (too big to fail) sehingga dapat menyebabkan dampak spillover negatif terhadap institusi lainnya.

Risiko sistemik menjadi polemik di Indonesia ketika pemerintah memutuskan untuk menyelamatkan Bank Century dengan cara mengambil alih (bail out) dengan biaya yang "kelewat mahal" karena bank tersebut dinyatakan sebagai bank gagal dan berdampak sistemik. Polemik ini terjadi karena belum ada kajian ilmiah maupun penelitian yang membahas risiko sistemik perbankan di Indonesia. 
Pengukuran probabilitas default bank yang dilanjutkan dengan pengukuran risiko sistemik memerlukan nilai pasar serta volatilitas aset sebagai variabel. Pada penelitian Lehar (2005) dan Adrian dan Brunnermeier (2009) menggunakan harga saham untuk bisa melakukan estimasi nilainya. Cooperstein, Pennacchi dan Redburn (2003) memberikan model untuk mengestimasi nilai pasar aset dan volatilitas aset dengan menggunakan laporan keuangan bank. Estimasi dilakukan bukan dengan menggunakan angka-angka neraca, melainkan didasarkan pada data laporan laba-rugi. Tudella dan Young (2003) menerapkan model Merton untuk mengestimasi probabilitas default dari perusahaan korporasi di Inggris sehingga dapat menentukan perusahaan tersebut gagal atau tidak gagal. Akan tetapi sebelumnya Black dan Cox (1976) melakukan generalisasi model dasar Merton yang mempelajari pengaruh obligasi dengan memasukkan faktor jaminan sebagai variabel.

Tahun 2013 Bank Indonesia sebagai regulator tertinggi perbankan nasional telah memasukkan fungsi systemic surveillance ke dalam framework SSK dengan kegiatan utama antara lain pemeriksaan bank dan LKBB yang berpotensi sistemik serta melakukan riset dan analisis terhadap sistem keuangan rumah tangga, korporasi dan sektoral.

Berdasarkan pengalaman tersebut maka penelitian tentang risiko sistemik untuk industri perbankan di Indonesia menjadi sangat penting dilakukan. Mengingat dampak dan besarnya biaya yang harus ditanggung apabila krisis sampai terjadi lagi di masa yang akan datang. Dengan dasar ini, paper ini mengukur risiko sistemik dan keterkaitan finansial perbankan di Indonesia dengan mengidentifikasi risiko setiap bank terhadap sistem perbankan. Karena belum semua bank go public maka pengukuran probabilitas default bank dan pengukuran risiko sistemik berdasarkan nilai pasar serta volatilitas aset yang diestimasi dengan menggunakan laporan keuangan bank. Estimasi dilakukan bukan dengan menggunakan angka-angka neraca, melainkan didasarkan pada data laporan laba-rugi.

Secara eksplisit, tujuan penelitian ini pertama adalah mengetahui nilai probabilitas default masing-masing bank berdasarkan model Merton; kedua, mengukur tingkat risiko secara individu masing-masing bank; ketiga, mengukur kontribusi risiko dari setiap individu bank terhadap risiko sistem perbankan secara keseluruhan; keempat, mengukur persentase perubahan risiko dari setiap individu bank terhadap risiko sistem perbankan secara keseluruhan; dan kelima, mengukur financial linkage antara bank satu dengan lainnya dalam sistem perbankan di Indonesia.

Paper ini diharapkan mampu memberikan kontribusi positif berupa masukan-masukan baru kepada regulator perbankan dan institusi terkait dalam penyusunan regulasi-regulasi industri perbankan demi terwujudnya stabilitas keuangan nasional dan juga untuk memperkaya khasanah studi empiris mengenai risiko sistemik industri perbankan di Indonesia.

Bagian kedua dari paper ini mengulas teori, bagian ketiga mengulas data dan metodologi yang digunakan, sementara hasil perhitungan dan analisisnya disajikan pada bagian keempat. Kesimpulan dan saran penelitian lebih lanjut disajikan pada bagian kelima sebagai penutup. 


\section{TEORI}

\section{Konsep Risiko Sistemik dan Kebangkrutan Bank}

Risiko kegagalan merupakan ketidakpastian kemampuan bank untuk membayar utang dan kewajiban. Sebelum default, tidak ada cara untuk membedakan tegas antara bank yang akan default dan tidak. Kita hanya membuat penilaian probabilistik dari kemungkinan gagal. Akibatnya, bank umumnya membayar spread atas tingkat standar-bebas bunga yang sebanding dengan probabilitas default untuk mengkompensasi pemberi pinjaman.

Default merupakan peristiwa yang cukup langka. Sejumlah perusahaan khas memiliki probabilitas default sekitar 2 persen pada setiap tahun, namun tidak ada variasi dalam probabilitas standar di perusahaan (Moodys KMV, 2003).

Default pada satu unit perusahaan berpotensi memberikan dampak bagi industri secara keseluruhan. Menurut Adrian dan Brunerrmeir (2009) risiko sistemik dinyatakan sebagai suatu kemungkinan apabila suatu institusi mengalami distress, hal ini dapat memicu institusi lain dalam industri perbankan menjadi distress sehingga dapat menyebabkan bank run dan runtuhnya sistem keuangan perbankan. Sedangkan menurut Acharya (2001), risiko sistemik merupakan risiko kegagalan bersama yang timbul dari hubungan antara return pada asset dari sisi neraca bank.

De Bandt dan Hartmann (2000) mengemukakan tiga ciri pokok yang saling terkait dalam sistem keuangan yang dapat memberikan dasar untuk menjelaskan hipotesis financial fragility yaitu:

a. Struktur perbankan maupun lembaga keuangan lainnya dimana bank umumnya mencadangkan sedikit asetnya untuk memenuhi penarikan deposito.

b. Interkoneksitas lembaga keuangan melalui eksposur langsung dan sistem pembayaran.

c. Intensitas informasi dari kontrak keuangan dan masalah kredibilitas artinya ekspektasi nilai aset tersebut di masa mendatang dan arus kas yang dijanjikan dalam kontrak akan terpenuhi.

\section{Penyebab dan Indikator Kebangkrutan}

Mongid (2000) menulis bahwa menurut Hermsillo (1996) kegagalan bank yang sering disebut dengan kebangkrutan bank terdiri dari dua konsep yang berbeda, pertama adalah economic failure atau insolvency pasar; sebuah situasi dimana kekayaan bersih bank menjadi negatif, atau jika bank tidak dapat melanjutkan operasinya tanpa mendatangkan kerugian yang akan berakibat dengan segera pada kekayaan bersih negatif. Kedua, official failure, tipe kegagalan yang dapat diamati karena sebuah an official agency mengumumkan kegagalan kepada publik. Official failure terjadi ketika regulator bank bahwa institusi tidak akan lama berjalan. 
Secara umum, kita dapat membedakan sumber kegagalan bank, yakni:

1. Ekspansi kredit bank yang berlebihan.

2. Informasi asimetri mengakibatkan pada ketidakmampuan deposan untuk menilai aktiva bank secara akurat, khususnya ketika kondisi ekonomi bank memburuk.

3. Goncangan dimulai dari luar sistem perbankan, lepas dari kondisi keuangan bank, yang menyebabkan penabung mengubah preferensi likuiditasnya atau menyebabkan pengurangan pada cadangan bank.

4. Pembatasan institusional dan hukum yang memperlemah bank dan menyebabkan kebangkrutan.

\section{Model KMV Merton}

Model Merton menunjukkan ekuitas dapat dihitung harganya dan probabilitas kegagalan dapat diestimasi di bawah beberapa asumsi. Nilai ekuitas dapat ditentukan dengan standard Black-Scholes dalam bentuk:

$$
\begin{aligned}
& \mathrm{E}=\mathrm{A}_{\mathrm{t}} \Phi\left(\mathrm{d}_{1}\right)-\mathrm{L} \mathrm{e}^{-\mathrm{r}(\mathrm{T}-\mathrm{t})} \Phi\left(\mathrm{d}_{2}\right) \\
& \mathrm{d}_{1}=\frac{\ln A_{t}+\left(\mathrm{r}+\frac{1}{2} \sigma^{2}\right)(\mathrm{T}-\mathrm{t})-\ln L}{\sigma \sqrt{\mathrm{T}-\mathrm{t}}} \text { dan } \mathrm{d}_{2}=\mathrm{d}_{1}-\sigma \sqrt{\mathrm{T}-\mathrm{t}}
\end{aligned}
$$

Probabilitas default dirumuskan sebagai:

$$
\mathrm{PD}=\Phi\left(\frac{\ln \left(L / A_{t}\right)-\left(\mu-\frac{1}{2} \sigma^{2}\right)(T-t)}{\sigma \sqrt{T-t}}\right)
$$

dan jarak panjang untuk default (distance to default, DD) dinyatakan:

$$
\mathrm{DD}=\frac{\ln \mathrm{A}_{\mathrm{t}}+\left(\mu-\frac{1}{2} \sigma^{2}\right)(\mathrm{T}-\mathrm{t})-\ln \mathrm{L}}{\sigma \sqrt{\mathrm{T}-\mathrm{t}}}
$$


dan probabilitas default diringkas menjadi PD $=\Phi(-D D)$.

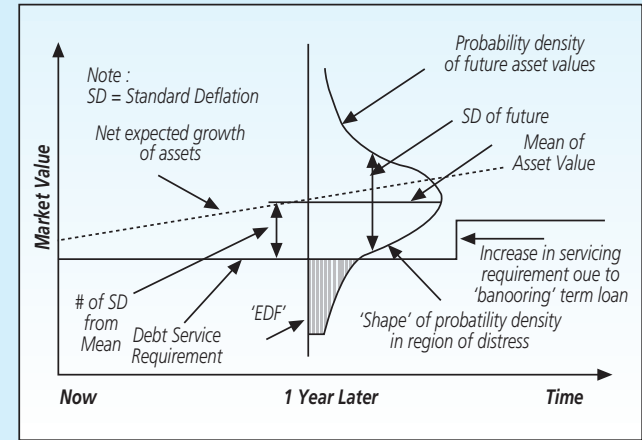

Gambar 1. Probabilitas default atau terhadap nilai asset. Default terjadi bila nilai aset akhir berada di bawah titik default (daerah diarsir) Crosbie dan Bohn (2003)

\section{Estimasi Arus Kas dan Nilai Pasar Aset}

Cooperstein, Pennachi dan Redburn (1995) mengestimasi nilai pasar aset dan volatilitas menggunakan laporan keuangan dan data laporan laba-rugi. Estimasi terhadap persamaan proses otoregresif arus kas dilakukan dengan metode analisis panel data.

$$
\mathrm{C}_{\mathrm{i}, \mathrm{t}}=\theta_{\mathrm{t}}+\rho \mathrm{C}_{\mathrm{i}, \mathrm{t}-1}
$$

Ekuitas pasar $\mathrm{E}_{\mathrm{t}}$ dapat dihitung sebagai nilai sekarang (present value) dari seluruh arus kas yang diharapkan di masa mendatang yaitu:

$$
\begin{aligned}
E_{t} & =\sum_{j=1}^{\infty} \frac{\exp ^{C_{t+\Delta j}}}{(1+r)^{\Delta j}} \\
& =\frac{\theta+\rho C_{t}}{(1+r)^{\Delta}}+\frac{\theta(1+\rho)+\rho^{2} C_{t}}{(1+r)^{2 \Delta}}+\frac{\theta\left(1+\rho+\rho^{2}\right)+\rho^{3} C_{t}}{(1+r)^{3 \Delta}}+\ldots .
\end{aligned}
$$

Bentuk yang lebih sederhana:

$$
E_{t}=\frac{\rho}{(\pi-\rho)} C_{t}+\frac{\theta \pi}{(\pi-1)(\pi-\rho)}
$$


Selanjutnya, menurut Loffler dan Posch (2007) estimasi terhadap nilai pasar aset dan volatilitas aset dilakukan dengan pendekatan iterasi. Estimasi proses stokastik dari aset setiap bank menggunakan model Black-Scholes terhadap nilai ekuitas pasar dan nilai buku hutang. Teknik ini dilakukan dengan mengambil nilai awal volatilitas (misal $\sigma_{0}$ ) untuk menghitung asetnya. Selanjutnya nilai aset ini kemudian digunakan untuk menghitung volatilitas untuk menghitung return asetnya yang kemudian digunakan kembali untuk merevisi nilai volatilitas awal $\sigma_{\mathrm{o}}$ (proses iterasi). Proses iterasi ke $k+1$ dilanjutkan dengan menghitungan nilai aset pasar yang ditunjukkan persamaan berikut sampai diperoleh konvergensi antara nilai volatilitas $\sigma_{\text {o }}$ dan $\sigma$.

$$
A_{t}=\frac{E_{t}+L e^{-r(T-t)} \Phi\left(d_{2}\right)}{\Phi\left(d_{1}\right)}
$$

\section{Pengukuran Risiko Sistemik}

Alternatif pertama yang dapat digunakan adalah Value at Risk (VaR). VaR adalah suatu metode pengukuran risiko yang menggunakan teknik statistik. Menurut Jorion (2001), secara umum VaR didefinisikan sebagai suatu metode yang digunakan untuk mengukur kerugian maksimum yang mungkin terjadi karena dalam periode dan tingkat kepercayaan tertentu.

$$
\mathrm{VaR}=\mu-\alpha \sigma
$$

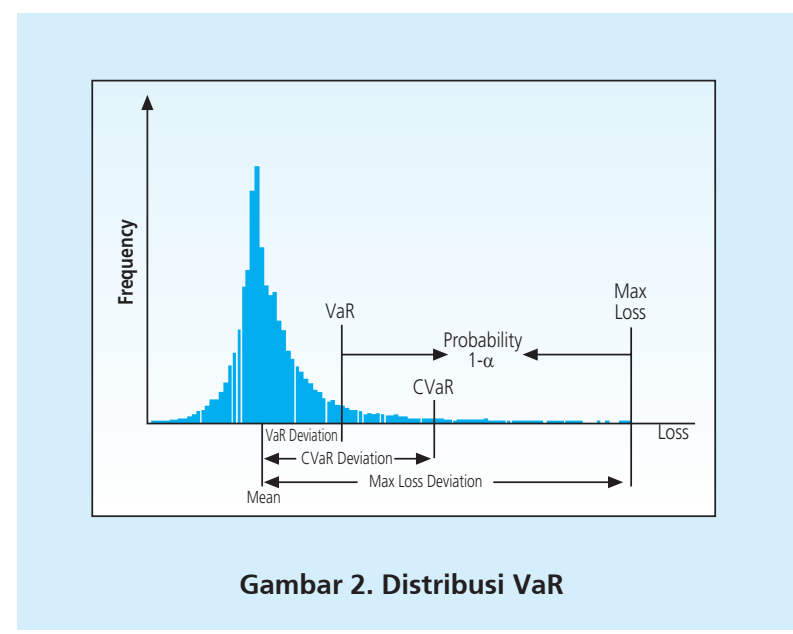

Alternatif kedua adalah dengan financial linkage. Risiko bank yang berhubungan satu bank dengan bank lain dapat dilihat dari keterkaitan keuangan. Konsepnya adalah bagaimana Value at Risk individu bank dapat terpengaruh jika bank lainnya sedang dalam keadaan distress. Oleh karena itu dibutuhkan parameter lain yakni menghitung CoVaR(A|B) yaitu CoVaR bank A yang dikondisikan terhadap bank B yang mengalami distress. 
Menurut Roengpitya dan Rungcharoenkitkul (2010) konsep ini dipandang sebagai eksternalitas yang tidak dapat diperoleh dengan hanya memperhatikan nilai risiko idividu. Hal ini dikarenakan kontribusi risiko individu yang dikondisikan oleh risiko individu bank lain $\triangle \mathrm{CoVaR}(\mathrm{A} \mid \mathrm{B})$ menggambarkan sejumlah kelebihan dari Value at Risk bank $\mathrm{A}$ yang terpisah dari Value at Risk bank A itu sendiri yang disebabkan oleh bank B. Sedangkan untuk mengukur persentase tambahan value at risk terhadap bank $\mathrm{A}$ apabila value at risk bank $\mathrm{B}$ berada dalam kondisi distress menggunakan $\% \Delta \operatorname{CoV} R(A \mid B)$. Semakin besar persentase kontribusi value at risk bank $B$ terhadap value at risk bank $A$, maka bank $B$ semakin sistemik terhadap bank $A$.

\section{METODOLOGI}

\section{Teknik Pengolahan Data}

Penelitian ini bersifat eksploratori dalam mengukur risiko sistemik individu bank terhadap sistem perbankan. Terdapat 4 (empat) tahap pengolahan data, sebagaimana diuraikan beikut.

Tahap pertama adalah menghitung nilai pasar aset perbankan, khsususnya bagi perbankan yang belum go public. Cooperstein, Pennacchi dan Redburn (2003) memberikan model untuk mengestimasi nilai pasar dan volatilitas aset dengan menggunakan laporan keuangan bank. Dalam paper ini, estimasi nilai pasar atas aset bank dilakukan dengan menggunakan data laporan laba-rugi.

Return dari aset masing-masing bank dan return aset sistem perbankan dinyatakan sebagai:

$$
X_{t}^{i}=\left(\frac{A_{t}^{i}-A_{t-1}^{i}}{A_{t-1}^{i}}\right) \text { dan } X_{t}^{\text {sys }}=\left(\frac{A_{t}^{\text {sys }}-A_{t-1}^{\text {sys }}}{A_{t-1}^{\text {sys }}}\right)
$$

dengan $A_{t}^{\text {sys }}=\sum_{i} A_{t}^{i} . \mathrm{X}_{\mathrm{t}}^{\text {sys }}$ menunjukkan return dari total aset dari keseluruhan sistem perbankan; dan $\mathrm{A}_{\mathrm{t}-1}^{\text {sys }}$ menunjukkan total aset sistem perbankan periode sebelumnya.

Untuk mendapatkan variasi waktu atas distribusi antara $X^{i}$ dan $X^{\text {sys }}$, distribusiini diestimasi sebagai fungsi dari serangkaian variable makro yang dapat mempengaruhi besarnya return aset. Dalam tahap ini, teknik pengolahan data yang digunakan adalah regresi Generalize Autoregressive Conditional Heteroschedastic atau GARCH $(1,1)$. Spesifikasi persamaan untuk mengestimasi nilai return dari aset bank adalah:

$$
\begin{aligned}
& \mathrm{X}_{\mathrm{t}}^{\mathrm{i}}=\alpha^{\mathrm{i}}+\beta^{\mathrm{i}} \mathrm{M}+\varepsilon_{\mathrm{t}}^{\mathrm{i}} \\
& \mathrm{X}_{\mathrm{t}}^{\mathrm{sys}}=\alpha^{\text {sys }}+\beta^{\text {sys }} \mathrm{M}+\varepsilon_{\mathrm{t}}^{\text {sys }}
\end{aligned}
$$


Tahap kedua adalah menghitung probability of default individual bank dan sistem perbankan secara umum. Lehar (2005), dan Adrian dan Brunnermeier (2009) menggunakan harga saham untuk mengestimasi besaran probabiltas default ini. Dalam penelitian ini, kami mengestimasi nilai VaR individu dan VaR sistem perbankan menggunakan spesifikasi berikut:

$$
\begin{aligned}
& \operatorname{VaR}_{\mathrm{t}}^{\mathrm{i}}=\hat{\alpha}^{\mathrm{i}}+\hat{\beta}^{\mathrm{i}} \mathrm{M} \\
& \mathrm{VaR}_{\mathrm{t}}^{\text {sys }}=\hat{\alpha}^{\text {sys }}+\hat{\beta}^{\text {sys }} \mathrm{M}
\end{aligned}
$$

dengan $\mathrm{VAR}_{\mathrm{t}}^{\mathrm{i}}$ adalah value at risk dari bank $i$ pada periode $t$, dan $\mathrm{VAR}_{\mathrm{t}}$ sys adalah value at risk system perbankan pada periode $t$. $\mathrm{M}$ merupakan vektor variabel makro meliputi SBI, JIBOR dan IHSG; ketiganya dihitung dalam nilai pertumbuhannya.

$$
\mathrm{SBI}_{\mathrm{t}}=\frac{\mathrm{SBI}_{\mathrm{t}}-\mathrm{SBI}_{\mathrm{t}-1}}{\mathrm{SBI}_{\mathrm{t}-1}} \quad \mathrm{JIBOR}_{\mathrm{t}}=\frac{\mathrm{JIBOR}_{\mathrm{t}}-\mathrm{JIBOR}_{\mathrm{t}-1}}{\mathrm{JIBOR}_{\mathrm{t}-1}} \quad \mathrm{IHSG}_{\mathrm{t}}=\frac{\mathrm{IHSG}_{\mathrm{t}}-\mathrm{IHSG}_{\mathrm{t}-1}}{\mathrm{IHSG}_{\mathrm{t}-1}}
$$

Tahap ketiga adalah menghitung parameter Conditional Value at Risk (CoVaR) yang berbasis pada Value at Risk pada individu bank dan keseluruhan sistem perbankan. Besaran CoVaR ini sesungguhnya mencerminkan risiko sistemik dalam pengertian pengaruh suatu bank terhadap system perbankan secara keseluruhan. Secara teknis, estimasi CoVaRi dilakukan dengan menggunakan koefisien hasil estimasi return sistem perbankan dan mensubstitusi hasil estimasi $V_{a R}{ }_{t}$ pada koefisien $\gamma^{\text {sysli: }}$

$$
\begin{aligned}
& X_{t}^{s y s}=\alpha^{s y s \mid i}+\beta^{s y s \mid i} M+\gamma^{s y s \mid i} X_{t}^{i}+\varepsilon_{t}^{s y s \mid i} \\
& \operatorname{CoVaR} t_{t}^{i}=\hat{\alpha}^{s y s \mid i}+\hat{\beta}^{s y s \mid i} M+\hat{\gamma}^{s y s \mid i} V^{i} R_{t}^{i}
\end{aligned}
$$

dimana: CoVaR ${ }_{t}$ adalah conditional value at risk sistem perbankan pada VaR bank $i$; sementara $\hat{\alpha}^{\text {sysli }}, \hat{\beta}^{\text {sysli }}, \hat{\gamma}^{\text {sysli }}$ merupakan parameter yang diestimasi. Langkah selanjutnya adalah melakukan perhitungan kontribusi risiko sistemik dari system perbankan dari setiap individu bank dalam bentuk:

$$
\Delta \mathrm{CoVaR}_{\mathrm{t}}^{\mathrm{i}}=\mathrm{CoVaR}_{\mathrm{t}}^{\mathrm{i}}-\mathrm{VaR}_{\mathrm{t}}^{\mathrm{sys}}
$$

Tahap keempat dalam pengolahan data adalah perhitungan financial linkage. Dalam paper ini digunakan empat langkah berikut:

a. Mengestimasi persamaan $\operatorname{CoVaR}(\mathrm{A} \mid \mathrm{B})$ yang merupakan value at risk bank $\mathrm{A}$ yang dikondisikan terhadap value at riskbank $\mathrm{B}$ : 


$$
\mathrm{X}_{\mathrm{t}}^{\mathrm{A}}=\alpha+\beta^{\mathrm{A}} \mathrm{M}+\gamma \mathrm{X}_{\mathrm{t}}^{\mathrm{B}}+\varepsilon_{\mathrm{t}}^{\mathrm{A}, \mathrm{B}}
$$

b. Estimasi CoVaR (A|B)-nya

$$
\operatorname{CoVaR}(\mathrm{A} \mid \mathrm{B})_{\mathrm{t}}=\hat{\alpha}^{\mathrm{A}}+\hat{\beta}^{\mathrm{A}} \mathrm{M}+\hat{\gamma} \operatorname{VaR}_{\mathrm{t}}^{\mathrm{B}}
$$

C. Tingkat marginalitas atau perubahan $\Delta \mathrm{CoV} R(A \mid B)$ :

$$
\Delta \operatorname{CoVaR}(\mathrm{A} \mid \mathrm{B})_{\mathrm{t}}=\operatorname{CoVaR}(\mathrm{A} \mid \mathrm{B})_{\mathrm{t}}-\operatorname{VaR}(\mathrm{A})_{\mathrm{t}}
$$

d. Analisis financial linkage antar-bank dengan mengukur persentase perubahan risiko bank A yang dikondisikan bank B:

$$
\% \Delta \operatorname{CoVaR}(\mathrm{A} \mid \mathrm{B})_{\mathrm{t}}=\frac{\operatorname{CoVaR}(\mathrm{A} \mid \mathrm{B})_{\mathrm{t}}-\operatorname{VaR}(\mathrm{A})_{\mathrm{t}}}{\operatorname{VaR}(\mathrm{A})_{\mathrm{t}}}
$$

\section{Sumber Data}

Data dalam penelitian ini meliputi data arus kas bulanan, kapitalisasi ekuitas, nilai aset dan utang serta variable makro (SBI rate, JIBOR dan IHSG) serta laporan keuangan tiap bulan periode 2002 - 2013. Sumber data dalam penelitian diperoleh dari hasil publikasi 30 bank umum yang sudah go public dan belum go public. Ini mencakup 10 bank dengan total Asset di atas Rp50 triliun, 10 bank dengan total aset di atas Rp10 triliun sampai Rp50 triliun dan 10 bank dengan aset dibawah Rp10 triliun.

Laporan keuangan diambil dari laporan CFS bank ke Bank Indonesia dan suku bunga SBI diperoleh dari Bank Indonesia. JIBOR berasal dari Indonesian Capital Market Directory dan IHSG bersumber pada situs Bursa Efek Indonesia (BEI).

\section{HASIL DAN ANALISIS}

\subsection{Analisis Probabilitas Default}

Terjadinya default pada suatu bank berpotensi mempengaruhi bank-bank lain sehingga akan terjadi persoalan risiko sistemik. Oleh karenanya, kegagalan sebuah bank merupakan risiko yang harus terukur dan disikapi secara rasional, sehingga upaya pencegahan kegagalan bank harus dilakukan sejak awal.

Banyak faktor yang mempengaruhi kegagalan bayar sebuah. Return dari nilai pasar aset dan volatilitasnya merupakan dua variabel utama yang diperlukan untuk menghitung probabilitas default pada model Merton. Sebelum default, tidak ada cara yang dapat membedakan secara 
tegas antara bank yang akan mengalami default dan tidak default. Kita hanya dapat menilai dan menghitung peluang defaultnya. Dalam hal ini, setiap bank akan membayar premi yang sebanding dengan probabilitas default untuk mengkompensasi pemberi pinjaman atas ketidakpastian ini.

Hasil penelitian ini menunjukkan bahwa untuk bank-bank besar, akumulasi rata-rata probabilitas risiko default mencapai 42,36 persen selama periode penelitian. Probabilitas default rata-rata maksimum sebesar 93,62 persen, dijumpai pada Bank T yang memiliki rating terendah C. Sementara rata-rata minimumnya mencapai 16,9 persen yaitu risiko default Bank $D$, yang memiliki rating $A$.

\begin{tabular}{|c|c|c|c|c|}
\hline \multicolumn{5}{|c|}{$\begin{array}{c}\text { Tabel } 1 \\
\text { Probabilitas Default dan Rating Bank }\end{array}$} \\
\hline \multirow[b]{2}{*}{ Nama Bank } & \multirow{2}{*}{$\begin{array}{l}\text { Aset } \\
\text { (Rp. Miliar) } \\
\text { Iterasi } \mathbf{k + 1}\end{array}$} & \multicolumn{2}{|c|}{ Probabilitas Defaut (PD) } & \multirow[b]{2}{*}{ Rating } \\
\hline & & Rata-rata & $\begin{array}{l}\text { PD pada Selang } \\
\text { Kepercayaan } 95 \%\end{array}$ & \\
\hline Bank A & 303.775 & $35,27 \%$ & $34,6-35,9 \%$ & BBB \\
\hline Bank B & 219.993 & $38,00 \%$ & $37,0-39,0 \%$ & BB \\
\hline Bank C & 171.630 & $42,94 \%$ & $42,5-43,4 \%$ & BB \\
\hline Bank D & 216.581 & $16,97 \%$ & $16,1-17,9 \%$ & A \\
\hline Bank E & 44.445 & $60,27 \%$ & $60,0-60,5 \%$ & B \\
\hline Bank F & 51.004 & $44,98 \%$ & $44,0-46,0 \%$ & BB \\
\hline Bank G & 27.385 & $48,03 \%$ & $47,5-48,6 \%$ & BB \\
\hline Bank H & 45.600 & $34,47 \%$ & $33,7-35,3 \%$ & BBB \\
\hline Bank I & 31.760 & $53,02 \%$ & $52,3-53,7 \%$ & B \\
\hline Bank J & 36.074 & $49,63 \%$ & $48,9-50,4 \%$ & BB \\
\hline Bank K & 3.453 & $49,25 \%$ & $48,7-49,8 \%$ & BB \\
\hline Bank L & 11.598 & $54,59 \%$ & $54,2-55,0 \%$ & B \\
\hline Bank M & 5.077 & $64,58 \%$ & $63,5-65,6 \%$ & B \\
\hline Bank N & 14.418 & $42,30 \%$ & $41,8-42,8 \%$ & BB \\
\hline Bank O & 4.236 & $69,82 \%$ & $69,6-71,0 \%$ & CCC \\
\hline Bank P & 9.361 & $36,54 \%$ & $35,1-38,0 \%$ & BB \\
\hline Bank Q & 16.831 & $40,92 \%$ & $40,1-41,7 \%$ & BB \\
\hline Bank R & 13.757 & $37,32 \%$ & $36,3-38,4 \%$ & BB \\
\hline Bank S & 8.838 & $93,60 \%$ & $93,4-93,8 \%$ & $C$ \\
\hline Bank T & 9.282 & $93,62 \%$ & $93,6-93,6 \%$ & C \\
\hline Bank U & 1.841 & $51,55 \%$ & $51,2-51,9 \%$ & B \\
\hline Bank V & 2.840 & $42,72 \%$ & $41,9-43,6 \%$ & BB \\
\hline Bank W & 1.731 & $48,45 \%$ & $48,1-48,8 \%$ & BB \\
\hline Bank X & 1.363 & $58,50 \%$ & $54,2-62,8 \%$ & B \\
\hline Bank Y & 1.023 & $64,62 \%$ & $64,5-64,8 \%$ & B \\
\hline Bank Z & 847 & $64,84 \%$ & $64,3-65,4 \%$ & B \\
\hline Bank AA & 423 & $69,74 \%$ & $69,7-69,8 \%$ & CCC \\
\hline Bank AB & 326 & $65,37 \%$ & $65,2-65,5 \%$ & CCC \\
\hline Bank AC & 166 & $78,28 \%$ & $78,1-78,5 \%$ & $\mathrm{CC}$ \\
\hline Bank AD & 703 & $57,85 \%$ & $57,6-58,2 \%$ & B \\
\hline \multicolumn{5}{|c|}{$\begin{array}{l}\text { Sumber : Data Olahan. } \\
\text { Keterangan : AAA }=(0-5 \%) ; A A=(5-15 \%) ; A=(15-25 \%) \\
\qquad B B B=(25-35 \%) ; B B=(35-50 \%) ; B=(50-65 \%) \\
\quad C C C=(65-75 \%) ; C C=(75-85 \%) ; C=(85-95 \%) ; D=95 \%+\end{array}$} \\
\hline
\end{tabular}


Mengacu pada matriks migrasi, dapat diamati bahwa potensi Bank D mengalami risiko default dalam waktu satu tahun sangat kecil sebesar 0,04 persen. Bahkan pada bank dalam kondisi sangat goyah, kemungkinan pailit atau menunggak pembayaran juga kecil yakni hanya sebesar 0,01 persen. Secara umum, bank-bank dengan rating A probabilitas risiko default masih dibawah 1 persen yaitu 0,04 persen. Meski demikian, peluang migrasi ke rating AAA (perusahaan berkualitas terbaik, layak dan stabil) juga kecil yakni 0,07 persen.

Peluang cukup besar migrasi bank dengan rating $A$ ke rating AA yaitu 2,25 persen. Namun demikian angka ini tergolong masih rendah karena masih di bawah 5 persen. Adapun probabilitas migrasi bank dengan rating BBB ke rating $A$ atau ke rating BB hampir sama sekitar 4 persen, dan peluang mempertahankan pada rating yang sama dalam satu tahun hampir 90 persen.

Bank A dan Bank H masuk dalam klasifikasi BBB dengan nilai probabilitas default 35 persen. Bank ini dapat disebut bank sehat dan kondisi keuangannya memuaskan. Kemampuan mempertahankan rating BBB cukup besar hingga mencapai 89,3 persen. Akan tetapi peluang untuk meningkatkan rating ke $A, A A$ atau $A A A$ juga rendah, masing-masing dengan probabilitas migrasi 4,83 persen; 0,25 persen dan 0,03 persen. Meski susah untuk meningkat, namun probabilitas default atau mengalami kebangkrutan juga sangat kecil yakni 0,22 persen.

\subsection{Analisis Risiko Sistemik}

\section{VaR Individu Bank dan VaR Sistem}

Hasil estimasi menunjukkan rata-rata VaR individual bank mencapai -29,87 persen. Besarnya VaR rata-rata ini disumbang oleh VaR dari Bank S dan Bank T lebih dari 50 persen. Kedua bank ini memiliki kinerja rendah dengan rating C. Secara agregat, VaR sistem perbankan di Indonesia memiliki probability of default yang kecil, ditunjukkan oleh VaR sistem sebesar $-3,04$ persen.

Berdasarkan hasil penelitian, bank-bank yang berkinerja rendah seperti Bank S, Bank T dan Bank $X$, memiliki fluktuasi return asset yang sangat besar dibandingkan dengan bank lainnya. Paper ini mengkonfirmasi bahwa nilai rata-rata VaR bank tersebut merupakan VaR terbesar dibandingkan dengan VaR bank lainnya, menunjukkan risiko individu yang besar pada Bank S, Bank T dan Bank $X$ tersebut. 


\begin{tabular}{|c|c|c|c|c|c|c|c|}
\hline \multirow{3}{*}{ No } & \multirow{3}{*}{ Nama Bank } & \multicolumn{4}{|c|}{$\begin{array}{c}\text { Tabel } 1 \\
\text { Risiko Individu dan Risiko Sistem Perbankan }\end{array}$} & & \\
\hline & & Risiko I & dividu & \multirow{2}{*}{ No } & \multirow{2}{*}{ Nama Bank } & \multicolumn{2}{|c|}{ Risiko Individu } \\
\hline & & VaR & Peringkat & & & VaR & Peringkat \\
\hline 1 & Bank A & $-5,01 \%$ & 28 & 17 & Bank Q & $-8,63 \%$ & 17 \\
\hline 2 & Bank B & $-7,88 \%$ & 19 & 18 & Bank R & $-7,50 \%$ & 21 \\
\hline 3 & Bank C & $-5,66 \%$ & 27 & 19 & Bank S & $-437,7 \%$ & 1 \\
\hline 4 & Bank D & $-2,07 \%$ & 30 & 20 & Bank T & $-112,3 \%$ & 2 \\
\hline 5 & Bank E & $-13,84 \%$ & 11 & 21 & Bank U & $-7,28 \%$ & 23 \\
\hline 6 & Bank F & $-7,31 \%$ & 22 & 22 & Bank V & $-7,80 \%$ & 20 \\
\hline 7 & Bank G & $-6,05 \%$ & 25 & 23 & Bank W & $-8,97 \%$ & 16 \\
\hline 8 & Bank H & $-8,63 \%$ & 18 & 24 & Bank X & $-37,51 \%$ & 3 \\
\hline 9 & Bank I & $-12,99 \%$ & 12 & 25 & Bank Y & $-15,01 \%$ & 10 \\
\hline 10 & Bank J & $-11,16 \%$ & 14 & 26 & Bank Z & $-20,09 \%$ & 7 \\
\hline 11 & Bank K & $-6,03 \%$ & 26 & 27 & Bank AA & $-18,89 \%$ & 8 \\
\hline 12 & Bank L & $-11,96 \%$ & 13 & 28 & Bank AB & $-15,72 \%$ & 9 \\
\hline 13 & Bank M & $-22,92 \%$ & 6 & 29 & Bank AC & $-32,04 \%$ & 4 \\
\hline 14 & Bank N & $-3,95 \%$ & 29 & 30 & Bank AD & $-10,76 \%$ & 15 \\
\hline 15 & Bank O & $-23,13 \%$ & 5 & 31 & SISTEM & $-3,04 \%$ & - \\
\hline 16 & Bank P & $-7,19 \%$ & 24 & & & & \\
\hline
\end{tabular}

\section{Kontribusi Risiko Individu Bank Terhadap Sistem Perbankan}

Pengukuran besarnya risiko suatu bank terhadap sistem perbankan, memerlukan identifikasi stuktur dan keterkaitan risiko lintas bank dalam sistem perbankan, dimana institusi saling terkoneksi dan dapat menyalurkan spillover negatif terhadap institusi lainnya. Untuk membedakan dengan terminology 'sistemik' yang umum dipahami, maka risiko sistemik individu ini kita artikan sebagai risiko yang dihasilkan oleh suatu bank terhadap risiko agregat sistem perbankan secara keseluruhan.

Dampak CoVaR individu bank terhadap VaR sistem bervariasi lintas bank, menandakan bahwa $\triangle$ CoVaR individu secara signifikan berbeda antar bank. Hubungan tingkat risiko individual bank (diukur dengan VaR individu) terhadap kontribusi risiko sistem perbankan (diukur dengan $\Delta$ CoVaR) dapat dilihat pada Tabel 3. Tabel ini menunjukkan bahwa bank dengan nilai VaR yang tinggi belum tentu memberikan kontribusi yang besar terhadap risiko sistem perbankan. Sebagai contoh, Bank A memiliki kontribusi risiko terhadap sistem perbankan yang paling besar $\Delta \mathrm{CoVaR}=-3,13$ persen (peringkat ke-1), memiliki unconditional VaR-nya hanya sebesar -5,01 persen (peringkat ke-28). Sebaliknya Bank S, yang memiliki risiko individu paling besar (peringkat ke-1), namun kontribusi risikonya terhadap sistem perbankan secara keseluruhan $\Delta$ CoVaR sebesar $-0,27 \%$ persen (peringkat ke-20). 

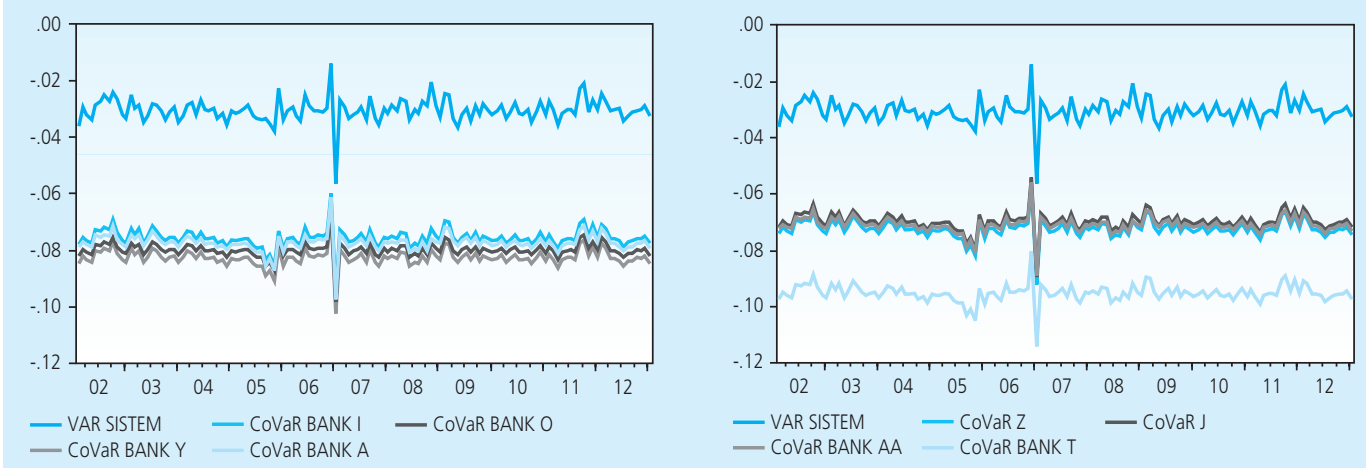

Gambar 3. VaR Sistem Perbankan dan CoVaR Bank

Persentase kontribusi risiko individual bank terhadap sistem, berhubungan linier dengan besarnya kontribusi bank tersebut terhadap risiko sistem perbankan secara agregat. Semakin tinggi kontribusi risiko, maka semakin mendekati potensi dampak sistemiknya terhadap perbankan secara agregat. Menurut penulis, kontribusi risiko terhadap perbankan dapat dikategorikan berdampak sistemik apabila kontribusi risiko sudah lebih dari 10 persen.

Dengan demikian titik utama seputar isu risiko sistemik adalah ketika satu bank berada dalam kesulitan, maka akan menimbulkan kepanikan dalam sistem keuangan, sehingga pada akhirnya menyebabkan kegagalan lembaga-lembaga lain. Ini dapat berujung pada krisis keuangan. Hal yang sangat dikhawatirkan adalah kegagalan simultan dari beberapa bank akan menghasilkan krisis ekonomi yang parah karena dampak dari krisis perbankan terhadap perekonomian sangat besar. Hoggarth (2002) menemukan bahwa kegagalan simultan mengakibatkan turunnya output PDB rata-rata 15 - 20 persen selama terjadinya krisis.

Mengacu pada threshold 10 persen diatas, penelitian ini telah mengkategorikan bankbank mana saja yang berpotensi memiliki dampak sistemik terhadap sistem perbankan secara keseluruhan. Hasil perhitungan (Tabel 3) menunjukkan bahwa dari 30 bank yang diobservasi, terdapat 19 bank yang berpotensi berdampak sistemik terhadap sistem perbankan, yaitu Bank A, Bank B, Bank C, Bank D, Bank O, Bank G, Bank F, Bank AA, Bank Y, Bank X, Bank E, Bank K, Bank Z, Bank H, Bank L, Bank I, Bank U, Bank J, Bank W. 


\begin{tabular}{|c|c|c|c|c|c|c|c|}
\hline \multicolumn{8}{|c|}{$\begin{array}{c}\text { Tabel } 3 \\
\text { Kontribusi Risiko Terhadap Sistem Perbankan }\end{array}$} \\
\hline \multirow{2}{*}{ Bank } & \multicolumn{2}{|c|}{ Risiko Individu } & \multicolumn{3}{|c|}{$\begin{array}{l}\text { Kontribusi Risiko Sistemik } \\
\text { Terhadap Sistem Perbankan }\end{array}$} & \multirow{2}{*}{$\begin{array}{c}\text { Risiko Sistemik Bank pada } \\
\text { Sistem Perbankan pada } \\
\text { threshold }=10 \%\end{array}$} & \multirow{2}{*}{ Rating } \\
\hline & VaR & Unit & $\% \Delta$ CoVaR & Urut & $\% \Delta$ CoVaR & & \\
\hline Bank A & $-5,01 \%$ & 28 & $-3,13 \%$ & 1 & $102,89 \%$ & Sistemik & BBB \\
\hline Bank B & $-7,88 \%$ & 19 & $-2,89 \%$ & 2 & $95,30 \%$ & Sistemik & BB \\
\hline Bank C & $-5,66 \%$ & 27 & $-2,82 \%$ & 3 & $92,88 \%$ & Sistemik & BB \\
\hline Bank D & $-2,07 \%$ & 30 & $-1,70 \%$ & 4 & $55,98 \%$ & Sistemik & $A$ \\
\hline Bank O & $-23,13 \%$ & 5 & $-1,52 \%$ & 5 & $50,11 \%$ & Sistemik & CCC \\
\hline Bank G & $-6,05 \%$ & 25 & $-1,47 \%$ & 6 & $48,27 \%$ & Sistemik & $\mathrm{BB}$ \\
\hline Bank F & $-7,31 \%$ & 22 & $-1,42 \%$ & 7 & $46,63 \%$ & Sistemik & BB \\
\hline Bank AA & $-18,89 \%$ & 8 & $-1,29 \%$ & 8 & $42,45 \%$ & Sistemik & CCC \\
\hline Bank Y & $-15,01 \%$ & 10 & $-1,28 \%$ & 9 & $42,17 \%$ & Sistemik & B \\
\hline Bank X & $-37,51 \%$ & 3 & $-1,12 \%$ & 10 & $36,76 \%$ & Sistemik & B \\
\hline Bank E & $-13,84 \%$ & 11 & $-0,86 \%$ & 11 & $28,30 \%$ & Sistemik & B \\
\hline Bank K & $-6,03 \%$ & 26 & $-0,85 \%$ & 12 & $27,88 \%$ & Sistemik & BB \\
\hline Bank H & $-8,63 \%$ & 18 & $-0,73 \%$ & 13 & $24,19 \%$ & Sistemik & BBB \\
\hline Bank Z & $-20,09 \%$ & 7 & $-0,73 \%$ & 14 & $24,00 \%$ & Sistemik & B \\
\hline Bank L & $-11,96 \%$ & 13 & $-0,69 \%$ & 15 & $22,56 \%$ & Sistemik & $\mathrm{B}$ \\
\hline Bank I & $-12,99 \%$ & 12 & $-0,55 \%$ & 16 & $18,23 \%$ & Sistemik & B \\
\hline Bank U & $-7,28 \%$ & 23 & $-0,40 \%$ & 17 & $13,19 \%$ & Sistemik & B \\
\hline Bank J & $-11,16 \%$ & 14 & $-0,38 \%$ & 18 & $12,47 \%$ & Sistemik & BB \\
\hline Bank W & $-8,97 \%$ & 16 & $-0,31 \%$ & 19 & $10,24 \%$ & Sistemik & $\mathrm{BB}$ \\
\hline Bank S & $-437,7 \%$ & 1 & $-0,27 \%$ & 20 & $8,76 \%$ & Tdk Sistemik & C \\
\hline Bank AB & $-15,72 \%$ & 9 & $-0,23 \%$ & 21 & $7,73 \%$ & Tdk Sistemik & $\mathrm{CCC}$ \\
\hline Bank V & $-7,80 \%$ & 20 & $-0,20 \%$ & 22 & $6,72 \%$ & Tdk Sistemik & BB \\
\hline Bank AC & $-32,04 \%$ & 4 & $-0,15 \%$ & 23 & $5,10 \%$ & Tdk Sistemik & $\mathrm{CC}$ \\
\hline Bank N & $-3,95 \%$ & 29 & $-0,15 \%$ & 24 & $4,97 \%$ & Tdk Sistemik & BB \\
\hline Bank T & $-112,3 \%$ & 2 & $-0,15 \%$ & 25 & $4,86 \%$ & Tdk Sistemik & $\mathrm{C}$ \\
\hline Bank M & $-22,92 \%$ & 6 & $-0,13 \%$ & 26 & $4,17 \%$ & Tdk Sistemik & B \\
\hline Bank AD & $-10,76 \%$ & 15 & $-0,12 \%$ & 27 & $4,08 \%$ & Tdk Sistemik & B \\
\hline Bank P & $-7,19 \%$ & 24 & $0,44 \%$ & 28 & $-14,65 \%$ & Tdk Sistemik & BB \\
\hline Bank R & $-7,50 \%$ & 21 & $0,46 \%$ & 29 & $-15,23 \%$ & Tdk Sistemik & BB \\
\hline Bank Q & $-8,63 \%$ & 17 & $0,53 \%$ & 30 & $-17,41 \%$ & Tdk Sistemik & BB \\
\hline Rata-rata & - & - & - & - & $26,45 \%$ & - & \\
\hline
\end{tabular}

Menarik untuk mencermati bahwa peringkat 19 bank yang tergolong berpotensi memiliki dampak sistemik terhadap perbankan, justru memiliki rating yang cukup baik dari B sampai $A$ dan hanya dua yang memiliki rating CCC yakni bank AA dan bank O. Pada sisi lain, bank yang tergolong tidak berpotensi memiliki dampak sistemik terhadap sistem perbankan, memiliki rentang rating dari CCC sampai BB. Meski demikian, sebagaimana ditegaskan pada awal bahwa penelitian ini merupakan penelitian eksploratif, dan hasil perhitungan dalam model ini paling tidak akan memberikan dasar diskusi yang terukur bagi seluruh stakeholder perekonomian. 


\section{Financial Linkage Perbankan}

Beberapa studi sebelumnya menyimpulkan bahwa ketika bank yang berukuran kecil sedang mengalami distress dan dinyatakan bangkrut bukan berarti bahwa bank tersebut tidak memiliki dampak yang sistemik yang besar. Hal ini dikarenakan kemungkinan bank run atau bank panic yang dapat timbul ketika kondisi tersebut terjadi, khususnya ketika kondisi makro ekonomi sedang mengalami penurunan (resesi ekonomi). Studi yang dilakukan oleh Simorangkir, (2006) menyatakan bahwa pada tekanan kondisi makroekonomi Indonesia yang terjadi pada tahun 1997-1998 secara signifikan berpengaruh terhadap terjadinya bank runs pada periode krisis perbankan saat itu.

Secara umum dapat dikatakan bahwa bank per individu, memiliki eksternalitas terhadap sistem yang ada sehingga dugaan terhadap potensi risiko sistemik pada individu bank tertentu layak menjadi perhatian bagi regulator. Menurut Roengpitya dan Rungcharoenkitkul (2009) bank yang tampaknya beroperasi secara prudent dan risiko individualnya rendah, bukan tidak mungkin dapat mengancam kelangsungan stabilitas sistem perbankan terutama pada kondisi tertentu.

Menurut hemat penulis, financial linkage CoVaR (A|B) secara signifikan dapat dipandang memiliki dampak risiko sistemik antarbank apabila tingkat persentase kontribusi $\% \Delta c o V a R$ (A|B) mencapai di atas 10 persen. Apabila sebuah bank memiliki tingkat financial linkage yang besar dengan bank lain, maka apabila mengalami kebangkrutan bank-bank lain akan menerima dampak yang lebih besar.

Dalam Tabel 4 menunjukkan bahwa bank-bank yang memiliki rata-rata $\% \Delta \mathrm{CoVaR}<10 \%$ atau tidak sistemik terhadap sistem perbankan juga memiliki rata-rata $\% \Delta \mathrm{CoVaR}(\mathrm{A} / \mathrm{B})<10 \%$ atau tidak sistemik terhadap bank-bank lain. Sedangkan dari 19 bank yang memiliki rata-rata $\% \Delta \mathrm{CoVaR}>10 \%$ atau sistemik terhadap sistem perbankan, 13 bank diantaranya memiliki ratarata $\% \Delta \operatorname{CoVaR}(\mathrm{A} / \mathrm{B})>10 \%$ atau sistemik terhadap bank-bank lain dan 6 bank diantaranya memiliki rata-rata $\% \Delta \operatorname{CoVaR}(\mathrm{A} / \mathrm{B})<10 \%$ atau tidak sistemik terhadap bank-bank lain.

Namun demikian, investigasi lebih lanjut dapat kita lakukan dengan melihat Tabel 5. Kita melihat bahwa bank-bank besar antara lain bank A, B, C dan D mampu mengkondisikan risiko VaR individu bank-bank lainnya dengan persentase cukup besar. Sebagai contoh, Bank A memiliki tingkat $\mathrm{VaR}$ individu $-5,01$ persen; kontribusi conditional value at risk Bank $\mathrm{A}$ terhadap Bank E atau $\triangle \mathrm{CoVaR}$ (E|A) sebesar -2,73 persen dan persentase kontribusi \% $\Delta \mathrm{CoVaR}$ (E|A) sebesar 19,75 persen. Sementara itu, Bank E dengan tingkat VaR individu -13,84 persen; 
kontribusi conditional value at risk bank E terhadap Bank A hanya -0,27 persen dan persentase $\% \Delta C O V a R(A \mid E)$ sebesar 5,43 persen. Ini menunjukkan bahwa Bank A mampu meningkatkan risiko terhadap Bank E dari VaR -13,84 persen menjadi -16,57 persen (potensi risiko sistemik). Pada sisi lain, Bank E hanya mampu menaikkan risiko VaR Bank A dari minus -5,01 persen menjadi -5,29 persen saja (potensi risiko tidak sistemik). Yang menarik adalah apabila kita mengamati bank menengah $\mathbf{S}$ yang memiliki asset tidak terlalu besar dan tidak sistemik terhadap sistem perbankan, hanya mampu mengkondisikan 6 bank lainnya dengan $\% \Delta \mathrm{CoV}$ aR $(A / B)>10 \%$ yaitu terhadap 78,48\% dari VaR bank $E, 14,60 \%$ dari VaR bank J, 35,62\% dari VaR bank P, 29,44\% dari VaR bank Q, 27,87\% dari VaR bank R dan 11,35\% dari VaR Bank Y. Bank E mampu mengkondisikan sebesar 14, 43\% terhadap VaR bank C, dimana Bank C mampu mengkondisikan bank-bank lainnya dengan persentase cukup besar karena bersifat sistemik. Selanjutnya, Bank J mampu mengkondisikan bank E, F, G, H dimana bank F dan G cukup besar mengkondisikan bank A, B, C, D dan E. Bank A, B, C dan D bersifat sistemik. Begitu seterusnya, bank akan saling mengkondisikan kepada bank lainnya. Oleh karena itu, ketika bank yang berukuran kecil sedang mengalami distress dan dinyatakan bangkrut bukan berarti bahwa bank tersebut tidak memiliki dampak yang sistemik yang besar.

Secara teoritis, jika ada effect negatif yang kuat dari kegagalan bank pada satu bank atau lebih, maka bank akan didorong untuk berinvestasi di industri yang sama untuk bertahan hidup atau gagal bersama. Strategi ini yang disebut risiko kolektif. Konsekuensi dari strategi ini adalah bahwa bank akan memiliki aset yang akan lebih tinggi berkorelasi yang mengarah ke kemungkinan yang lebih tinggi dari kegagalan bank bersama. Acharya (2001) menyebut adanya "eksternalitas negatif," yang besarnya tergantung pada ukuran bank gagal, keunikan bank gagal, serta kasus di mana bank-bank yang masih hidup tidak memanfaatkan dan melakukan pengambilalihan fasilitas bank gagal.

Penyebaran risiko bank gagal melalui interkoneksi lembaga dapat berasal dari kegagalan koordinasi dan krisis likuiditas. Krisis kepercayaan tidak harus berasal dari risiko kegagalan pihak lawan tetapi mungkin timbul dari suatu spiral nilai aset yang memburuk. Namun ada alasan lain dalam beberapa literatur yang menyatakan bahwa risiko sistemik hanya merupakan masalah koordinasi. Sehingga penyebaran krisis terhadap likuiditas ke institusi lain akan memberi dampak penularan yang sistemik pada perbankan. Oleh karena itu, risiko sistemik yang disebabkan oleh kekurangan likuiditas dalam sistem keuangan akan lebih parah menghantam bank-bank lain pada saat-saat guncangan yang menyebar dengan cepat. 


\begin{tabular}{|c|c|c|c|c|c|c|c|}
\hline \multicolumn{8}{|c|}{$\begin{array}{c}\text { Tabel } 4 \\
\text { Tingkat Risiko Sistemik dan Financial Linkage. (dalam persen) }\end{array}$} \\
\hline \multirow{2}{*}{ Bank } & \multicolumn{3}{|c|}{$\begin{array}{c}\text { Risiko Sistemik dan Persentase } \\
\text { Kontribusi dalam Sistem Perbankan } \\
\text { Keseluruhan }\end{array}$} & \multicolumn{3}{|c|}{ Financial Linkage (FL) } & \multirow{2}{*}{$\begin{array}{c}\text { Risiko Sistemik } \\
\text { Antarbank pada } \\
\text { thresholdFL= } \\
10 \%\end{array}$} \\
\hline & CoVaR & $\Delta$ CoVaR & $\% \Delta$ CoVaR & $\begin{array}{l}\text { Rata-rata } \\
\text { CoVaR } \\
\text { (AIB) }\end{array}$ & $\begin{array}{l}\text { Rata-rata } \\
\Delta \text { CoVaR } \\
\text { (AIB) }\end{array}$ & $\begin{array}{l}\text { Rata-rata } \\
\% \Delta \text { CoVaR } \\
\text { (AIB) }\end{array}$ & \\
\hline Bank A & $-6,16$ & $-3,13$ & 102,89 & $-31,84$ & $-1,12$ & 22,15 & Sistemik \\
\hline Bank B & $-5,93$ & $-2,89$ & 95,30 & $-31,51$ & $-0,88$ & 19,15 & Sistemik \\
\hline Bank C & $-5,86$ & $-2,82$ & 92,88 & $-33,62$ & $-2,92$ & 22,55 & Sistemik \\
\hline Bank D & $-4,74$ & $-1,70$ & 55,98 & $-31,75$ & $-0,92$ & 16,07 & Sistemik \\
\hline Bank E & $-3,90$ & $-0,86$ & 28,30 & $-38,61$ & $-8,19$ & 3,27 & Tdk Sistemik \\
\hline Bank F & $-4,45$ & $-1,42$ & 46,63 & $-31,46$ & $-0,82$ & 16,34 & Sistemik \\
\hline Bank G & $-4,50$ & $-1,47$ & 48,27 & $-32,17$ & $-1,48$ & 15,13 & Sistemik \\
\hline Bank H & $-3,77$ & $-0,73$ & 24,19 & $-29,61$ & 0,99 & 7,02 & Tdk Sistemik \\
\hline Bank I & $-3,59$ & $-0,55$ & 18,23 & $-30,46$ & $-0,01$ & 4,41 & Tdk Sistemik \\
\hline Bank J & $-3,42$ & $-0,38$ & 12,47 & $-31,87$ & $-1,36$ & 1,03 & Tdk Sistemik \\
\hline Bank K & $-3,88$ & $-0,85$ & 27,88 & $-31,00$ & $-0,31$ & 7,98 & Tdk Sistemik \\
\hline Bank L & $-3,72$ & $-0,69$ & 22,56 & $-31,45$ & $-0,97$ & 10,20 & Sistemik \\
\hline Bank M & $-3,16$ & $-0,13$ & 4,17 & $-31,10$ & $-1,00$ & 3,87 & Tdk Sistemik \\
\hline Bank N & $-3,19$ & $-0,15$ & 4,97 & $-29,74$ & 1,02 & 1,74 & Tdk Sistemik \\
\hline Bank O & $-4,56$ & $-1,52$ & 50,11 & $-32,12$ & $-2,02$ & 19,24 & Sistemik \\
\hline Bank P & $-2,59$ & 0,44 & $-14,65$ & $-31,14$ & $-0,50$ & 2,29 & Tdk Sistemik \\
\hline Bank Q & $-2,51$ & 0,53 & $-17,41$ & $-31,22$ & $-0,63$ & 3,46 & Tdk Sistemik \\
\hline Bank R & $-2,58$ & 0,46 & $-15,23$ & $-31,18$ & $-0,54$ & 2,76 & Tdk Sistemik \\
\hline Bank S & $-3,30$ & $-0,27$ & 8,76 & $-16,13$ & $-0,33$ & 3,63 & Tdk Sistemik \\
\hline Bank T & $-3,19$ & $-0,15$ & 4,86 & $-27,58$ & $-0,55$ & 6,43 & Tdk Sistemik \\
\hline Bank U & $-3,44$ & $-0,40$ & 13,19 & $-34,18$ & $-3,53$ & 10,65 & Sistemik \\
\hline Bank V & $-3,24$ & $-0,20$ & 6,72 & $-32,16$ & $-1,53$ & 5,64 & Tdk Sistemik \\
\hline Bank W & $-3,35$ & $-0,31$ & 10,24 & $-31,73$ & $-1,15$ & 7,74 & Tdk Sistemik \\
\hline Bank X & $-4,15$ & $-1,12$ & 36,76 & $-32,88$ & $-3,28$ & 28,36 & Sistemik \\
\hline Bank Y & $-4,32$ & $-1,28$ & 42,17 & $-33,47$ & $-3,09$ & 15,19 & Sistemik \\
\hline Bank Z & $-3,77$ & $-0,73$ & 24,00 & $-29,91$ & 0,29 & 10,28 & Sistemik \\
\hline Bank AA & $-4,33$ & $-1,29$ & 42,45 & $-32,35$ & $-2,10$ & 17,35 & Sistemik \\
\hline Bank AB & $-3,27$ & $-0,23$ & 7,73 & $-29,92$ & 0,44 & 4,08 & Tdk Sistemik \\
\hline Bank AC & $-3,19$ & $-0,15$ & 5,10 & $-31,68$ & $-1,89$ & 6,96 & Tdk Sistemik \\
\hline Bank AD & $-3,16$ & $-0,12$ & 4,08 & $-28,32$ & $-2,20$ & 0,69 & TdkSistemik \\
\hline
\end{tabular}




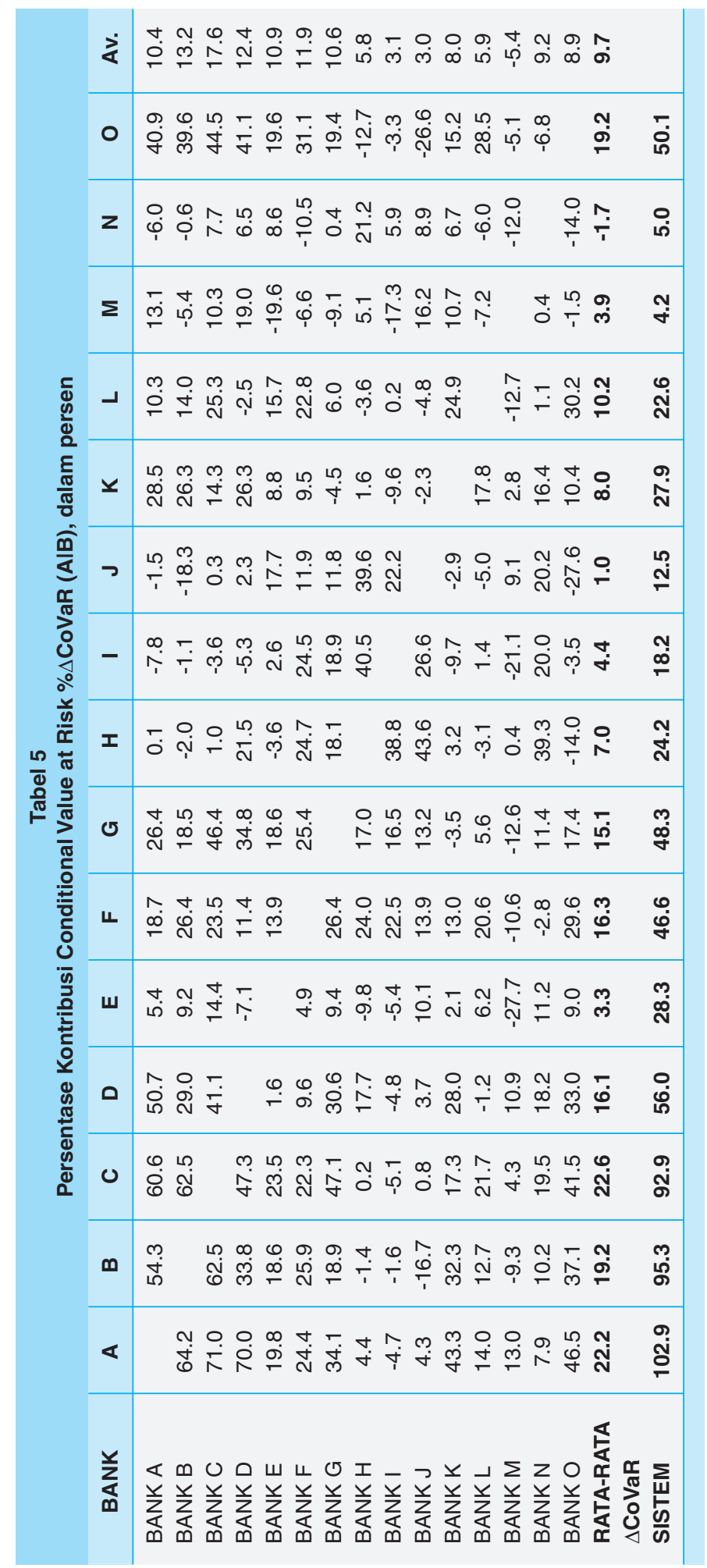




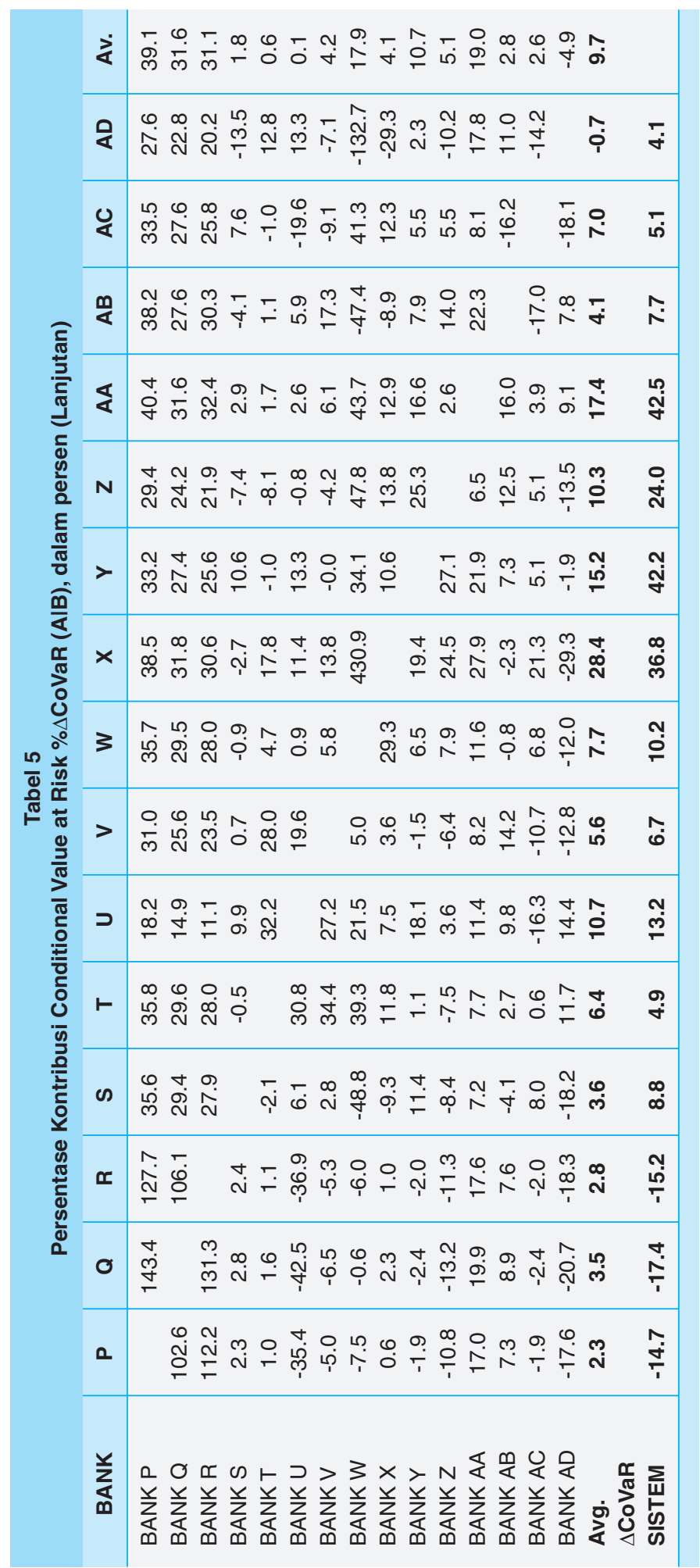




\section{KESIMPULAN}

Penelitian ini memberikan beberapa kesimpulan empiris menarik yang dapat menjadi wacana pembuka tentang resiko sistemik perbankan. Dengan menggunakan 30 bank umum sebagai sampel penelitian, kesimpulan empiris yang diperoleh, pertama, rata-rata probabilitas default bank selama periode penelitian (2002 - 2013) adalah sebesar 53,60 persen dengan standar deviasi 4,81 persen. Model Merton cukup memiliki keunggulan karena tidak membutuhkan asumsi tentang bentuk fungsional baik digunakan sebagai signal awal resiko dan potensi probabilitas default.

Temuan empiris kedua adalah bahwa probabilitas default perbankan sangat dipengaruhi oleh besarnya volatilitas return dari aset bank. Semakin tinggi fluktuasi volatilitas, semakin besar pula potensi risiko sebuah bank mengalami default dan atau sebaliknya.

Pada level individual bank, temuan empiris ketiga adalah bahwa risiko VaR individu bank ditemukan rata-rata sebesar -29,87 persen dan VaR sistem perbankan hanya -3,04 persen. Nilai unconditiona/ VaR masing-masing bank ini dapat digunakan untuk menggambarkan bagaimana risikonya terhadap sistem perbankan tersebut.

Dengan analisis financial linkage antarbank, penelitian ini memberikan kesimpulan keempat bahwa risiko individu bank yang dikondisikan terhadap risiko individu bank lainnya rata-rata $\operatorname{CoVaR}(\mathrm{A} \mid \mathrm{B})$ sebesar $-31,07$ persen. Masing-masing bank memberi tambahan risiko sangat beragam ketika bank tersebut mengalami distress.

Besarnya tambahan kontribusi risiko bank yang dikondisikan bank lain rata-rata sebesar $-1,21 \%$ dan rata-rata persentase kontribusi $\% \Delta C$ CoVaR(A|B) sebesar 9,69 persen. Parameter ini ternyata berhubungan secara linier dengan besarnya kontribusi risiko sistemik. Semakin tinggi kontribusi risiko, semakin tinggi pula persentase kontribusi risiko sistemiknya. Ini merupakan temuan empiris yang kelima.

Lima temuan empiris di atas menunjukkan bawha secara umum setiap bank memiliki eksternalitas terhadap sistem perbankan secara keseluruhan, sehingga dugaan terhadap potensi risiko sistemik pada individu bank tertentu layak menjadi perhatian bagi regulator. Bank-bank kecil maupun bank yang tampaknya beroperasi secara prudent dan risiko individualnya rendah, tidak mungkin dapat mengancam kelangsungan stabilitas sistem perbankan terutama pada kondisi tertentu. Temuan empiris dalam penelitian ini perlu dipertimbangkan oleh Pemerintah maupun otoritas keuangan (Bank Indonesia, Otoritas Jasa Keuangan maupun Lembaga Penjamin Simpanan), untuk dijadikan masukan dalam membuat peraturan dan kebijakan yang akurat.

Penelitian ini perlu dikembangkan lebih lanjut pertama dalam hal jumlah data observasi dan pengamatan perlu diperbanyak; kedua, perlunye mempertimbangkan peran faktor eksternal dalam pemodelan persamaan financial linkage; ketiga, perlunya mengkonfrontasikan dan menganalisis lebih lanjut besaran threshold yang digunakan dalam menentukan resiko sistemik perbankan. 


\section{DAFTAR PUSTAKA}

Acharya, Viral V. (2009). A Theory os Systemic Risk and Design of Prudential Bank Regulation. PhD Dissertation of New York University

Adrian, t., dan Brunnermeier, (2009). Covar. Princeton University, Department of Economics, Bendheim Center for Finance, Princeton,

Black, F and Cox, J (1976), 'Valuing corporate securities: some effects ofbond indenture provisions', Journal of Finance, Vol. 31, pages 351-67.

Cooperstein, R.,L., Pennacchi, G.G. Redburn, F.S. (2003). The Aggregate Cost of Deposit Insurance: A Multiperiod Analysis, Deparment of Finance University of Illinois.

Crosbie, P and Bohn, J. (2003). Modelling Default Risk. Moody's KMV Company.

De Bandt, O. and P. Hartmann, (2000). Systemic Risk: A Survey, CEPR Discussion Paper Series No. 2634.

Foster, G. (1986). Financial Statement Analysis. 2nd Ed. Prentice Hall.

Heffernan, S. (2005). Modern Banking. West Sussex. Joh Willey and Sons Ltd

Jorion, P. (2001). Value at Risk. 2nd ed., McGraw-Hill, New York.

KMV, (2003). Modeling Default Risk, Published by: Moody's KMV Company.

Lehar, Alfred. (2005). Measuring Systemic Risk: A Risk Management Approach, Journal of Banking \& Finance 29. Department of Business Studies, University of Vienna, Vienna, Austria.

Malik,I., (2013).Premi Berbasiskan Risiko Pada Lembaga Penjamin Simpanan. Program Pascasarjana, Universitas Indonesia. Jakarta.

Merton, R.C. (1974). On the Pricing of Corporate Debt: The Risk Structure of Interest Rates. The Journal of Finance, Volume 29 Issue 2. New York.

Mongid, A. (2000). "Accounting Data and Bank Future Failure: A Model For Indonesia. Simposium Nasional Akuntansi

Roengpitya, R. dan Rungcharoenkitkul, P. (2010). Measuring Systemic Risk And Financial Linkages In The Thai Banking System, Bank of Thailand, Jurnal Bank of Thailand, Bangkok. 
Saheruddin, H. (2009). Mengungkap Praktek Herding pada Perbankan Indonesia dengan Metode K-Means Cluster dan LSV Measure: Implikasinya Terhadap Risiko Sistemik. Tesis, Fakultas Ekonomi, Universitas Indonesia, Jakarta.

Tudela and Young, G., (2003). A Merton Model Approach to Assessing the Default Risk of UK Public Companies Bank of England.

Zebua, A., (2010). Analisis Resiko Sistemik Perbankan di Indonesia. Program Pascasarjana, Institut Pertanian Bogor (IPB), Bogor. 
126 Buletin Ekonomi Moneter dan Perbankan, Oktober 2013

Halaman ini sengaja dikosongkan 